\title{
MANS SE ERVARING VAN EENSAAMHEID NA DIE VERLIES VAN 'N LEWENSMAAT: 'N BESKRYWING VAN NARRATIEWE PASTORALE BETROKKENHEID
}

Author:

A de Beer ${ }^{1}$

Affiliation:

${ }^{1}$ Faculty of Theology, University of the Free State

\section{Correspondence to:}

Annamarie de Beer

\section{Postal Address:}

University of the Freestate,

Nelson Mandela Drive,

Bloemfontein

Email:

adebeer@compuking.co.za

Dates:

15 August 2016

How to cite this article: De Beer, A. , 2016. "Mans se ervaring van eensaamheid na die verlies van 'n lewensmaat: 'n Beskrywing van narratiewe pastorale betrokkenheid". KOERS - Bulletin for Christian Scholarship, 81(1). Available at: http://dx.doi.org/10.19108/ KOERS.81.1.2231

\section{Copyright:}

(c) 2015. The Author(s)

Published under the Creative Commons Atribution License.
Die doel van hierdie studie is om die fenomeen van eensaamheid by mans na die verlies van ' $n$ lewensmaat te ondersoek. Dit behels navorsing wat die voorkoms, betekenis en die belewenis van eensaamheid na die verlies van 'n eggenoot kan verhelder. Die navorsing is gegrond in praktiese teologie. Dit word nagevors vanuit postmoderniteit as paradigma met 'n sosiaalkonstruksionistiese diskoers as epistemologiese vertrekpunt soos verwoord in die narratiefhermeneutiese benadering. Verskeie aksies onderliggend aan deelnemende aksienavorsing vir die insameling van data word as deel van 'n kwalitatiewe navorsingsbenadering benut. Meganismes onderliggend aan die narratiewe benadering wat korreleer met beginsels onderliggend aan deelnamende aksie-navorsing word geïmplementeer by die insameling van data. Waardevolle alternatiewe, wat ' $n$ bydrae kan lewer in die hantering van eensaamheid, word vanuit die gespreksbenadering verken en beskryf. Antropologiese paradigmas word verhelder vanuit die siening dat die mens 'n komplekse wese is, wat deur sy/haar eie narratiewe sy omstandighede konstrueer. Met die studie word gevind dat mans eensaamheid kan ondervind na afsterwe van 'n lewensmaat. Hulle ondervind ook ' $n$ behoefte aan 'n verbintenisfiguur wat kan help om hul eensaamheid te hanteer.

Men's experience of loneliness after the loss of a spouse: A description of a narrative pastoral engagement.

The purpose of this study is to explore the phenomenon of loneliness that men experience after the loss of a spouse. It contains research to illuminate the occurrence, meaning and perception of loneliness after the loss of a spouse. The research is founded in practical theology and researched from within a postmodern paradigm, with a social constructionist discourse as epistemological point of departure as it is expressed in the narrative hermeneutic approach. Several actions subjacent to participatory action research are employed and form part of a qualitative research. Mechanisms of the narrative approach that resonate with the principles of participatory action research are used to collect the information. Valuable significant alternatives to cope with loneliness are explored by using the conversational approach. Anthropological paradigms are clarified from the view that a human being is a complex entity that constructs his/her own circumstances through narratives. Important findings of this research are that men can experience loneliness after the loss of a spouse and they are in need of an attachment figure to help them to cope with loneliness. 


\section{INLEIDING}

Eensaamheid in hierdie studie kan gesien word as 'n gevoel van verlatenheid wat mans ervaar na die verlies van hul lewensmaat. Dit is 'n gewaarwording wat tot 'n mens se diepste wese spreek. Die behoefte van die individu om erken te word en aan iemand te behoort, word daardeur weerspieël (Blackwell 2010). Eensaamheid is die subjektiewe ongemak wat mense ervaar wanneer daar in hul sosiale verhoudings ' $n$ belangrike eienskap ontbreek (Taylor, Peplau \& Sears 2003:234). Navorsing het reeds sedert die laat 1960's bevestig dat eensaamheid wydverspreid is (Perlman 1989:19). Eensaamheid kan 'n persoon se welstand ondermyn aangesien dit die mens op psigiese sowel as fisieke vlak beïnvloed (Doman 2007:2). Hieruit kan afgelei word dat eensaamheid universeel voorkom en die individu se lewe kan oorneem. Dit kan ons denke beïnvloed wat weer'n impak op ons lewenskwaliteit kan hê (Deut 30:19). In 'n verdere ontwikkeling van die navorsing deur De Beer en Van den Berg (2012) oor eensaamheid by vroue na die verlies van 'n lewensmaat, word daar in hierdie beskrywende navorsingsverslag in besonder gelet op die invloed van eensaamheid na die verlies van 'n lewensmaat by enkele mans in die Kroonstad-omgewing. Die titel verwys weliswaar na mans in die algemeen maar dit moet in gedagte gehou word dat hierdie studie op drie mans se individuele en persoonlike ervaring fokus en daar nie veralgemeen kan word nie.

Mans en vroue sal die ervaring van eensaamheid verskillend beleef, want Ons dink nie dieselfde nie, ons praat nie dieselfde nie, ons luister nie dieselfde nie, ons lyk nie dieselfde nie, ons speel nie dieselfde nie en ons ontspan nie dieselfde nie (Leaf 2012:vii). Ons is verskillende wesens en as man en vrou geskep deur God (Gen 1:27).

Hierdie navorsing handel nie oor persoonlikheidsverskille tussen mans en vroue nie, maar wel oor die uniekheid van die belewenis van eensaamheid by mans na die verlies van ' $\mathrm{n}$ lewensmaat. Die verklaring van die navorsing word georden deur die gebruik van die onbepaalde lidwoord om aan te dui dat slegs 'n moontlike uitbeelding van 'n narratiewe pastorale betrokkenheid beskryf word.

\section{KONTEKS VAN DIE STUDIE}

Hierdie navorsing veronderstel 'n bepaalde betrokkenheid van navorser en gespreksgenote wat aan die navorsing deelneem (Müller, Van Deventer \& Human 2001:76). Medenavorsing fokus daarop om mense se lewens op diensvaardige wyse te skakel en kanale te skep om inligting te deel (Morgan 2000:119). As pastorale terapeut in Kroonstad het die navorser met talle manlike gespreksgenote, wat eensaamheid beleef, gesprekke gevoer. Mans wat woonagtig is in Kroonstad en eensaamheid beleef na die verlies van ' $n$ lewensmaat is as medenavorsers betrek.

Die outeur het besluit om die belewenis van eensaamheid by drie mans tussen die ouderdomme van 60 en 70 jaar, wat hulle lewensmaats verloor het, te ondersoek. Daar is op hierdie drie mans besluit aangesien verlies van 'n lewensmaat en gevolglike eensaamheid 'n onafwendbare deel van veroudering is. Hulle verbeeld die ouderdomsgroep waarin die verlies van intieme verhoudings in 'n latere lewe algemeen is (Louw 2008:503) en omdat hulle ervarings ' $n$ weerspieëling van ander gespreksgenote se belewenisse is. In gesprekke met die mans het hulle betekenisvolle inligting verskaf wat kan help om mans se begrip met betrekking tot eensaamheid te verhelder. Hierdie navorsing behels dus die verhale van hierdie drie mans wat spontaan en vrywilliglik hulle ervaring en lewensomstandighede konstrueer en in taal uitbeeld. In hulle verhale wat handel oor die belewenis van eensaamheid word die manne se verhouding met daardie ervarings beskryf. Om 'n etiese praktyk te verwesenlik is vrywillige deelname van mense waaroor en waarvoor navorsing gedoen word nodig (Kotzé 2002:27). Die mans se identiteit word beskerm deur die gebruik van skuilname en hulle verhale word met hulle toestemming in die navorsing gebruik. Slegs fragmente van gesprekke met medenavorsers word op relevante plekke en in direk-gedokumenteerde aanhalings weergegee. Verslae van onderhoude, asook skriftelike toestemming vir gebruik van aanhalings, is by die pastorale terapeut geliasseer. Subjektiewe integriteit behels persoonlike betrokkenheid by 'n gespreksgenoot, wat bevorderlik vir inlewing en verstaan is.

Hulle verhale word vervolgens inleidend en kortliks deur die navorser op sirkulêre wyse binne die beweging van die praktykteorie-model (Browning 1991:34-39) geskets ten einde die leser ' $n$ blik op hulle lewens te gee. Uittreksels van die mans se verhale weerspieël die geheelbeeld van hulle ervaring. Alles in hul verhale het betekenis, niks is toevallig nie:

Kobus is 63 jaar oud en het sy vrou twee jaar gelede verloor. Sy het pankreaskanker gehad en is 'n maand nadat sy gediagnoseer is oorlede. Hulle het twee seuns uit hul huwelik. Hy het twee kleinkinders waarvoor hy baie lief is. Sy seuns was albei oorsee en het hom nie ondersteun tydens sy verlies nie. Hy was baie eensaam na sy vrou se dood en het ' $n$ maat en versorger gemis. Sy het altyd vir die huis, kos en klere gesorg en alle praktiese takies self verrig. Hy moes skielik self kruideniersware aankoop en homself versorg. Dit was vir hom traumaties.

Bernard is 70 jaar oud en het sy vrou twee jaar gelede verloor nadat sy borskanker gekry het. Sy het 'n jaar lank behandeling gekry en hulle hele lewensprogram het rondom die behandelings, dokters en hospitale gedraai. Hulle het drie kinders uit die huwelik. Sy kinders het hom ondersteun maar het self die rouproses moeilik verwerk en was nie altyd beskikbaar nie. Hulle het glad nie oor sy vrou gepraat nie en dit was vir hom 'n groot leemte. Hy vind dat hy naweke alleen is en alhoewel hy lees en in die tuin werk is hy baie eensaam. Sy vrou het al hulle finansies hanteer. Hy het elke maand sy salaris vir haar gegee en sy het hom geld gegee wanneer hy dit nodig het. Hy het nooit haar hantering van hulle geld bevraagteken nie aangesien sy dit goed hanteer het. Na haar dood moes hy leer hoe om self ' $n$ begroting op te stel en aankope daarvolgens doen. 
Louwtjie is 69 jaar oud en sy vrou is drie jaar gelede oorlede. Sy het kolonkanker gehad wat verspreid was. Dit was vir hom baie traumaties en hy het die dokters en ander mediese personeel geblameer vir haar dood. Hulle het drie seuns gehad, maar een is oorlede na 'n tref-en-trap ongeluk. Hy sukkel om aan te pas op sosiale vlak en is meesal by sy huis alleen. Hy voel dat ander hom nie aanvaar nie omdat hy nou 'n alleenloper is. Sy vrou het vir hom sy identiteit bepaal.

Die konteks waarbinne verhale vertel word is van belang, want dit maak die verhale sosiale skeppinge. Die pastoral-teologiese ondersoek dui daarop dat daar 'n noue deelgenootskap met die dinamika van die gemeenskap van gelowiges is. Volgens McClure (2012:269) is pastorale sorg nou verbonde aan die Christelike tradisie en het uit omstandighede van die gemeentelike lewe ontstaan. Dit is dus wesenlik deel van 'n godsdienstige lewe. Die wyse waarop eensaamheid die mans se sinvolle funksionering raak word pastoraal terapeuties verken om die belewenis en hantering daarvan te verhelder.

Pastorale ondersteuning binne 'n geloofsgemeenskap veronderstel ook omgee vir mekaar. Louw (2008:27) noem dat daar binne 'n geloofsgemeenskap ruimte moet wees vir koinonia om mense wat geheel moet word te ondersteun en hulle by te staan om weer betekenis te vind. Die gespreksgenote se verhale in hierdie ondersoek is tweeledig en behels nie slegs die verlies en meegaande eensaamheid nie, maar ook 'n behoefte om op 'n spirituele vlak binne die geloofsgemeenskap te kommunikeer. Die volgende direkte aanhalings uit die gesprekke het daarop gedui.

Kobus: 'Ek het met my predikant gaan praat omdat ek gevoel het dat hy dalk vir my kan raad gee oor die hantering van hierdie gevoel van eensaamheid.'

Bernard: 'Dit het gehelp dat ek met mense van ons kerk kon praat oor my eensaamheid. Hulle kon my nie help nie maar ek het beter gevoel nadat ek dit bespreek het.'

Louwtjie: 'Die eensaamheid het my gevang en ek het na die pastorale terapeut van ons kerk gegaan vir hulp.'

\section{DOEL VAN DIE NAVORSINGSPROJEK}

Daar word gepoog om drie geïdentifiseerde mans, binne 'n bepaalde sosiale konteks, se belewenis van eensaamheid na die verlies van 'n eggenoot te ondersoek. Hierdie navorsing fokus slegs op mans se belewenis van eensaamheid weens die feit dat mans en vroue verlies verskillend ervaar (Smit 2000:5).

\section{NAVORSINGSVERWAGTINGE}

Moontlike uitkomste word weerspieël in die volgende navorsingsverwagtinge:

- Mans kan (intense) eensaamheid ervaar nadat 'n eggenote oorlede is;
- Na die verlies van 'n lewensmaat kan mans, wat eensaamheid belewe, voel asof die lewe nie meer sin en betekenis het nie;

- Die mans se geloof speel 'n wesenlike rol in hulle hantering van eensaamheid; en

- Pastorale terapie kan mans se perspektiewe rondom eensaamheid positief verander.

\section{NAVORSINGSPROSEDURE EN METODOLOGIE}

Hierdie studie maak gebruik van 'n kwalitatiewe navorsingsbenadering vir die insameling van inligting. Verskillende handelswyses word benut om hierdie inligting te verkry. Volgens Swinton en Mowat (2006:29) stel hierdie metode die navorser in staat om die sosiale wêreld van individue en gemeenskappe te verken in 'n poging om toegang daartoe te verkry en om die unieke wyses waarop hulle dit beleef, te kan verstaan. Volgens Denzin en Lincoln (1994:3) kan die nut van kwalitatiewe navorsing gevind word in die variasie van moontlike diskoerse wat vir die navorsing gebruik kan word.

Deur gebruik te maak van Browning (1991:34-39) se benadering van 'n sirkelbeweging tussen praktyk en teorie, word gesprekke geformuleer en omskryf. Die navorser gebruik die narratiewe benadering om met behulp van ongestruktureerde sirkulêre vrae daarna te streef om gedrag te verstaan. Hierdie soort vrae berus op belangstelling in mense se stories (Botha 2001:17). Daar word slegs gepoog om insig te verkry in die wyse waarop die mans eensaamheid ervaar en navorsingsresultate is nie geldig vir die hele bevolking nie. Fragmente van hulle gesprekke word aangehaal en geplaas om relevansie van die navorsing aan te dui.

Metodologie behels die navorser se persepsie oor hoe om meer uit te vind omtrent die realiteit of die wêreld (Schurink 1998:240). Hierdie praktiese teologiese studie behels dus verkenning van menslike ondervinding en die begeerte om teologies oor daardie belewenis na te dink (Swinton \& Mowat 2006:v).

\section{WESE EN PLEK VAN DIE NAVORSING}

Die navorser werk vanuit sy of haar verwysingsraamwerk en begrip oor die dialoog met die aksies, betekenisse en voorafgaande begrip van die betrokke persone (Browning 1991:48). Inligting word ook daarvolgens geïnterpreteer. Vervolgens word die paradigma en epistemologie verhelder.

\section{PARADIGMA}

Schurink (1998:240) stel dit dat 'n paradigma 'n stel oortuigings is. Dit behels die aard of realiteit van die wêreld, hoe dit geken kan word en hoe mens kan sien hoe die navorser se persepsie daarvan gevorm word. Postmoderniteit behels volgens Van den Berg (2006:168-171) subjektiewe integriteit, beperktheid van taal en die misterie van verstaan. Dit erken dus veelvuldige interpretasies (De Beer \& Van den Berg 2012:110) 
en is sensitief vir die eenvoudige en reglynige betekenis van byvoorbeeld Bybeltekste vir dié werklikheid. Hierdie stel oortuigings vorm die operasionele raamwerk waarbinne die navorsing geplaas word. Postmoderniteit sal dus die inhoud en omvang van die navorsingsverhaal bepaal.

Die sosiale konstruksiediskoers behels volgens Müller (1996:33) 'n gedeelde konstruk binne 'n interpreterende gemeenskap. Die uitgangspunt van die sosiale konstruksie-diskoers word deur Freedman en Combs (1996:6) gesien as oortuigings, waardes, instellings, gewoontes, etikette, wette en verdeling van arbeid, wat die sosiale werklikheid vorm. Daar word na die narratiewe van medenavorsers geluister vanuit 'n koinoniale verwantskap. Binne die gemeenskap van gelowiges word saam na verborge en nuwe betekenisse gesoek. Die veronderstelling is dat pastorale sorg religeuse aandag teenoor mekaar omvat (McClure 2012:269). Hierdie wyse van dataversameling word as deelnemende aksie-navorsing gesien. Die mans se verhale word ondersoek om op grond van die bevindinge hulle te bemagtig dat hulle weer kan betekenis vind in die lewe en sinvol kan funksioneer.

Vervolgens word die epistemologie verhelder wat die vraagstuk oor hoe daar tot kennis gekom kan word en wat die bron van kennis is (Louw 1999:10) behels.

\section{EPISTEMOLOGIE}

Kwalitatiewe navorsing maak gebruik van verskillende vakgebiede en tegnieke om inligting te verkry (Schurink 1998:240). Hierdie studie is gebaseer op 'n kwalitatiewe navorsingsepistemologie. Dit behels die navorser se persepsie met betrekking tot die realiteit of die wêreld. Kennis word dus op verskillende maniere verkry. Die volgende perspektiewe in die verkryging van kennis sluit in:

- Volgens die narratiewe benadering gaan dit om die vertel, sowel as die verstaan deur interpretasie, van die mans se verhale. Die narratiewe benadering staan in 'n hermeneutiese perspektief en probeer om wat in die pastorale ontmoeting gebeur te verduidelik en te beskryf (Ganzevoort \& Visser 2007:100). Met die vertel van hulle verhale is hulle besig om hul wêreld te (re-)konstrueer. Die mans se verhaal en God se verhaal moet in wisselwerking verkeer. Probleme moet met behulp van die Skrif geïnterpreteer en hanteer word. Die doel van die pastorale terapeut is die herstel van die God-mensverhouding. Die mans is medenavorsers en deelnemers aan die proses. Müller, Van Deventer en Human (2001:3) stel dit tereg dat die narratiewe navorser 'has subjective integrity in mind and strives for participatory observation'.

- Volgens die uitgangspunt van die sosiale konstruksiediskoers, is dit die oortuigings, waardes, instellings, gewoontes, etikette, wette en verdeling van arbeid wat die sosiale werklikheid vorm (Freedman \& Combs 1996:6). Peplau en Perlman (1982:4) sien eensaamheid grootliks as 'n sosiale konstruk. Die daaglikse interaksie van lede van 'n spesifieke kultuur konstrueer hulle werklikheid. Hulle kan ook in omgewings met verskillende werklikhede funksioneer. Die feit dat vrae geformuleer word as deel van narratiewe navorsing dui daarop dat die hermeneutiese wyse van vraagstelling die vertel van verhale aanmoedig. Dit bevestig ook dat die proses van ondervraging voortvloei uit die vraag (Josselson 1999:x). Die sosiale aard van konstrukte waarbinne die mans in 'n postmoderne konteks eensaamheid beleef word vanuit hierdie perspektief verhelder.

Bostaande perspektiewe verduidelik die wyses waarop kennis oor die unieke ervaring van eensaamheid van mans binne hulle konteks en as deel van die wederkerige versorging van gelowiges, ingewin word. Dit skakel aan by 'n praktiesteologiese hermeneutiek wat oor die interpretasie van menslike gedrag binne sosiale kontekste handel (Louw 1997:56). Aangesien hierdie 'n prakties-teologiese studie is, word die relevansie daarvan vervolgens verder bespreek.

\section{PRAKTIES-TEOLOGIESE PLASING}

Die studie vind aansluiting by die gedragsdimensie binne die praktiese teologie. Dit behels die gereedmaak en handelswyse van die navorsing. Praktiese teologie word volgens Müller (2009:205) gesien as altyd konkreet, lokaal en kontekstueel maar ook as iets wat verder strek as bepaalde (lokale) kontekste tot interdissplinêre aangeleenthede. Daar is 'n klemverskuiwing vanaf die subjektiewe tot die diskoersvlak. Eerstens moet daar na verhale van mense binne 'n konteks in werklike lewenssituasies geluister word (Müller 2009:205). Hierdie verhale word altyd geïnterpreteer.

Medenavorsing met gespreksgenote hou verband met beginsels onderliggend aan deelnemende aksienavorsing en daarom word die praxis beklemtoon. Kruger (2000:30) reken dat die praxis 'n beskrywende karakter dra. Die oogmerk van verstaan en interpreteer is om betekenisvolle verbande binne ('n) geloofsgemeenskap(pe) wat tot realisering van singewing as uitkoms kan lei, te ontdek (Müller 1996:8-12; Louw 1999: 22-23). Praktiese teologie word deur Browning (1991:9) beskryf as ' $n$ multi-dissiplinêre wyse om teologie aan te pak. Dit omvat praxis sowel as teorie en die twee staan in 'n voortdurende sirkulêre beweging teenoor mekaar (Browning 1991:6).

Daar is egter volgens Osmer (2008:328) 'n nuwe begrip en ontwikkeling binne die praktiese teologie. Dit omvat 'n aksie-begeleide konstruksie-teorie van die Christen-praxis in 'n spesifieke sosiale konteks waarin die erkenning van die normatiewe karakter van onderlinge koinoniale versorging, soos onder meer uitgedruk in die pastoraat, erken word. Hy identifiseer die volgende vier take wat daarmee verband hou (Osmer 2008:4-12):

- Die deskriptiewe-empiriese taak wat handel met die vraag oor wat aangaan of wat gebeur.

- Die interpreterende taak wat die vraag vra oor hoekom dit gebeur.

- Die normatiewe taak wat die vraag stel oor wat behoort te gebeur. 
- Die pragmatiese taak wat handel oor die vraag oor hoe gereageer kan word.

Volgens Fourie (2010:32) kan die onderlinge verhouding van Osmer se vier take as 'n hermeneutiese sirkel, waar elke taak deel van 'n groter interverwante geheel is, gesien word.

Beide praktiese teologie en die pastoraat fokus op die sinvolle funksionering en geestelike groei van mense. Die pastoraat veronderstel die ontmoetingsgebeure waartydens inligting ingewin word. Dit word vervolgens aan die orde gestel.

\section{PASTORAAT}

Pastoraat is geloofshulp, wat as lewenshulp aangebied word en kan wesenlik gesien word as 'n teologiese vakgebied. Volgens Louw (1999a:167) kan dit nie ontken word dat Rogers die oë van die pastoraat oopgemaak het vir liefde en waardering binne die pastorale ontmoeting nie. Dit poog om mense te help om sinvol te leef en om 'n samehang met hul verstaan van God, en basiese lewensvraagstukke, soos angs, skuld, wanhoop en vertwyfeling, te bewerkstellig. Heitink (1979:289-311) sien heling, bystand, begeleiding en versoening as funksies van die pastoraat. 'n Primêre taak van die pastor binne die geloofsgemeenskap is om na mense se verhale te luister en dit te interpreteer (Müller 1996:107). Die unieke karakter van die pastoraat kan in terme van pastorale sorg beskou word:

- Pastorale sorg gaan oor begrip en interpretasie vanuit die perspektief van geloof. Pastorale sorg kan gesien word as geloofsorg wat handel met die interpretasie van die teenwoordigheid en die wil van God, binne die parameters van ons menslike soeke na betekenis.

- Pastorale sorg streef na die ontwikkeling van toepaslike Godsbeelde en 'n geloofsvolwassenheid, om sodoende mense te help om verskillende lewensgebeurtenisse te kan hanteer. Hier speel die Bybel 'n vername rol.

- Pastorale sorg poog om die teenwoordigheid van God se Gees te beliggaam sodat mense genees en heel kan word. Dit poog om te lei, te onderhou en om mense te bemagtig. Dit behels ' $n$ breë veld van emosies, soos byvoorbeeld eensaamheid, ons behoefte aan hoop en 'n soeke na sin en betekenis.

- Pastorale sorg funksioneer binne die dinamiek van verhoudings en konteks. Daarom is die basiese vaardighede, naamlik empatie, interpatie en simpatie, van belang. "Pastoral care entails being with people where they are and meeting them in their being functions with deep concern and sincere empathy" (Louw 2008:75).

Hierdie karaktertrekke van die pastoraat handel primêr met die interaksie en kommunikasie van die ontmoeting tussen God en die mens. Daar word gepoog om God se wil met betrekking tot die vraag na die sin van die lewe, en omgekeerd, te vertolk sodat medegelowiges met vreugde en hoop kan leef (Louw 1999:2). Hierdie studie poog om deur pastorale ondersteuning die ervaring van eensaamheid by mans na vreugde en hoop om te skakel. Eensaamheid spreek tot 'n persoon se diepste wese en skep ' $n$ begeerte om 'n verhouding met die self, ander en God te hê (De Beer \& Van den Berg 2012:112). Die volgende fragmente van gespreksgenote verhelder die ervaring van die mans se verlies en meegaande eensaamheid.

Kobus: 'Ek het met my predikant gaan praat omdat ek gevoel het dat hy dalk vir my kan raad gee oor die hantering van hierdie gevoel van eensaamheid.'

Bernard: 'Dit het gehelp dat ek met mense van ons kerk kon praat oor my eensaamheid. Hulle kon my nie help nie maar ek het beter gevoel nadat ek dit bespreek het.'

Louwtjie: 'My vrou het my identiteit bepaal. Ek is verlore sonder haar. Niemand verstaan my en deel my diepste gevoelens nie. Dit is so eensaam en alleen sonder haar.'

Om die begrip eensaamheid te eksploreer is dit nodig om die dinamiek daarvan te verhelder.

\section{DIE SAMESTELLING VAN EENSAAMHEID}

Eensaamheid kan beskryf word, maar nie werklik gedefinieer word nie (Stokes 1989:59). Volgens Doman (2007:4) kan eensaamheid beskou word as 'n subjektiewe ervaring wat deur verskeie faktore beïnvloed word. Dit is 'n gebrek aan 'desired relational interaction' wat ' $n$ toestand van ontevredenheid met betrekking tot die kwaliteit en kwantiteit van interpersoonlike verhoudings skets (Spitzberg \& Hurt 1989:157).

Eensaamheid kan volgens Wintrob (1989:80) gesien word as 'n probleem wat ervaar word as gevolg van swak sosiale verhoudings, waar die basiese behoeftes van die persoon nie bevredig word nie, asook as 'n onaangename en soms pynlike verlange na meer interaksie as wat tans ervaar word. Eensaamheid is die gebrek aan gemeensaamheid, saamwees met ander, 'n gebrek aan intimiteit. Dit is nie die gevolg van alleen wees nie, dit is die gevolg van alleen voel. Dit blyk ook duidelik uit die volgende fragmente van die gesprekke met medenavorsers.

Kobus: 'Sy het vir alles gesorg in die huis. Nou moet ek self alles doen, want niemand wil help nie.'

Bernard: 'Niemand stel belang om my by te staan nie. Ek moet alleen inkopies doen en vir my kos maak.'

Louwtjie: 'Ons gesamentlike vriende het nie meer iets in gemeen met my nie. Dit voel of ek oral uitgestoot is.'

Veranderlikes wat ' $n$ rol speel by die ervaring van eensaamheid hou verband met die konteks waarin die mans hulle bevind, die verhouding wat hulle met hul oorlede vroue gehad het, asook ondersteuningstrukture wat beskikbaar is. Die volgende fragmente uit gesprekke toon dat elke man eensaamheid op sy eie unieke, persoonlike manier beleef. 
Kobus: 'Ek voel asof ek my een helfte verloor het.'

Bernard: 'My hart is stukkend. Haar plek is leeg.'

Louwtjie: 'Ek het met alles op haar gesteun en nou is daar niemand.'

Eensaamheid kan ook gekoppel word aan verskeie emosionele steurnisse wat onder meer' $n$ lae selfbeeld, depressie, selfmoordfantasieë en angs insluit (Spitzberg \& Hurt 1989:157). Dit spreek ook uit gesprekke met die mans.

Kobus: 'Ek moes my eie identiteit van vooraf weer vind.'

Bernard: 'Dit voel asof ek nie meer bestaan nie. Die lewe het nie meer sin nie'

Louwtjie: 'Alles het net vir my te veel geword. Ek sien nie meer kans om aan te gaan nie.'

Ander moontlike emosionele belewenisse bestaan ook na die verlies. In gevalle waar die oorledene 'n langdurige terminale siektetoestand gehad het en baie gely het, of waar daar 'n swak verhouding was, kan soms 'n mate van verligting ondervind word. In sodanige gevalle moet verligting volgens Louw (2008:555) gesien word as 'n normale reaksie wat positief kan wees indien dit gekombineer word met dankbaarheid. Hierdie navorsing handel egter slegs oor die gevoel van eensaamheid wat na die verlies ervaar word.

Die begrip van eensaamheid sal van persoon tot persoon verskil aangesien dit 'n persoonlike ervaring is. Dit is 'n unieke en subjektiewe ervaring vir elke persoon (Doman 2007:6). Eensaamheid kan verstaan word as skeidingsangs sonder 'n objek (Weiss 1989:10). Dit veroorsaak 'n behoefte aan 'n verbintenisfiguur (attachment figure) se gerusstellende teenwoordigheid. 'n Persoon sonder so 'n verbintenisfiguur kan eensaamheid beleef. Die mans het hulle vroue as hul verbintenisfiguur gesien en het dit verloor.

Kobus: 'Haar stem is stil. Daar is niemand om my intieme sake mee te bespreek nie.'

Bernard: 'Sy kan my nie meer ondersteun nie. Ek kan haar nie meer vashou en liefkoos nie.'

Louwtjie: 'Ons het soveel pret gehad. Die lewe is nou leeg en sonder plesier.'

Die verbintenisfiguur is van belang vir hierdie studie en word vervolgens verhelder aangesien dit 'n persoon is wat sekuriteit voorsien weens ' $n$ waarneembare en emosionele skakeling met die eensame.

\section{VERBINTENISFIGUUR (ATTACHMENT FIGURE)}

Persone wat eensaam is, het 'n behoefte aan gepaste en betekenisvolle verhoudings waarbinne interaksie kan plaasvind en emosionele ervarings gedeel kan word (Paul, Ayis \& Ebrahim 2006:221-232). Volgens Weiss (1989:11) is die veronderstelling dat dit iemand is wat genoeg omgee om met duidelike begrip te luister en wat toeganklik is vir vertroulike mededelings. So ' $n$ persoon blyk ' $n$ rol te speel in die belewenis van eensaamheid. Teenwoordigheid van 'n verbintenisfiguur kan help om angs wat tot depressie lei af te weer. Eensaamheid kan moontlik verlig word deur so 'n persoon te vind.

Gebrek aan 'n verbintenisfiguur word by die mans geassosieer met hulle lewensmaats wat hulle verloor het. Hulle aandag en denke fokus op die verlore objek en volgens Wood (1989:44-45) kan hierdie objek nie maklik vervang word deur 'n ander nie.

\section{VERHOUDINGS EN EENSAAMHEID}

'n Persoon kan volgens De Beer en Van den Berg (2012:113) van drie soorte verhoudings gedistansieer raak wanneer die persoon as gevolg van eensaamheid bewus gemaak word van die gebrek aan 'n verbintenisfiguur. Hierdie verhoudings handel oor die verhouding met die self, verhouding met ander en jou verhouding met God. Behoeftes, begeertes, wense en hoop ontstaan in die hart en soms is emosionele afsondering nodig om te hoor wat in die hart omgaan (Blackwell 2010). Sosiale afsondering skep eensaamheid wat meer te doen het met weerloosheid as met verlies van wense (Weiss 1989:13). Wanneer 'n persoon op sy eie in die wêreld moet leef skep dit behoeftes van aanvaarding, erkenning en liefde. Mense is nie heel op hul eie nie, hulle lewens moet vervleg wees met ander mense indien hulle vervul wil wees (Pike 1953:95). Eensaamheid skep 'n emosionele en geestelike verlange na God. ' $n$ Mens wil by die bron van jou bestaan en behoeftes uitkom (Blackwell 2010.)

\section{MOONTLIKE FAKTORE WAT 'N ROL SPEEL BY EENSAAMHEID}

Eensaamheid kan'n invloed op besluitneming van mense hê (Blackwell 2010). Dit kan ook 'n potensiële gevaar inhou vir die mens se gesondheid (Lauder, Sharkey \& Mummery 2004: 88-94). Die eensame persoon betree ' $n$ abnormale, eensame en onwelkome wêreld waar daardie persoon 'n eiland van swaarmoedigheid word (Kübler-Ross \& Kessler 1005:81-82). Daar word deur Perlman en Joshi (1989:67) beweer dat die eensame persoon dikwels matig depressief en geneig tot apatie is. Potgieter (2010) wys daarop dat eensaamheid ervaar kan word as 'n gevoel van isolasie, betekenisloosheid en verwerping, wat dikwels lei tot die ervaring van minderwaardigheid. Die volgende fragmente uit gesprekke met medenavorsers dui ook daarop.

Kobus: 'My vrou het gesorg dat ons gebalanseerde en gesonde maaltye eet. Ek voel so verlore en gee so min om vandat ek alleen is dat ek sommer net brood en grondboontjiebotter eet.'

Bernard: 'Sy het alles hanteer en ek is in die diep kant ingegooi, want ek weet nie eens watse kos om te koop 
nie. Ek koop vrugte en vars groente maar het nie lus om vir my alleen kos te maak nie.'

Louwtjie: 'Ek sorg vir gesonde kos maar dit word sleg in die yskas, want ek is alleen en eensaam en het nie lus daarvoor nie.'

Eensame persone openbaar dikwels 'n negatiewe oordeel oor die self en ander (Shaver \& Hazan 1989:117) en het 'n invloed op besluitneming.

\section{AANLEIDING TOT EENSAAMHEID}

Gebrek aan 'n verbintenisfiguur is een van die redes waarom 'n persoon eensaam voel (Weiss (1989:10). Eensaamheid ontstaan volgens Pike (1953:106) vanuit die gebrek aan 'n diepe, blywende basis van verbintenis tussen mense. Hierdie gebrek aan ondersteuning wat na verlies van hul eggenotes ontstaan het is vir die gespreksgenote moeilik om te hanteer. Dit blyk ook uit die volgende fragmente van gesprekke.

Kobus: 'Ek vertrou niemand meer nie, want ek kan nie alles met vriende bespreek nie.'

Bernard: 'Alles waaroor ek besluite moet neem is vir my te moeilik. Ek is so alleen.'

Louwtjie: 'Dit is vir my moeilik om alles wat opduik alleen te hanteer. Ek voel hopeloos.

Belewenis van eensaamheid kan chronies raak en die gespreksgenote kan begin glo dat hulleself die oorsaak van hulle eensaamheid is (De Beer \& Van den Berg 2012:114). Hierteenoor kan situasionele eensaamheid die persoon motiveer om die eensaamheid te hanteer deur interpersoonlike kontak te soek.

\section{TERAPEUTIESE BETROKKENHEID}

Die terapeutiese benadering is op die geestelike of spirituele versorging van die totale mens gerig. God se storie kan help om die verlede, sowel as die toekomsstorie só te herformuleer dat dit nuwe sin aan die hede gee. Met behulp van die hermeneutiese proses word die betekenis van eensaamheid vir die medenavorsers ondersoek. Hierdie benadering wil nie in die besonder verklaar nie (Louw 1999:23), maar wil eerder verbande ontdek met die oog op singewing. Die pastoraat is by die verstaan van menslike probleme betrokke (Endres 2009:117). Die terapeut is die instrument waardeur mense bemagtig word om hulle huidige situasie deur nuwe lense te kan sien. Met behulp van die narratiewe benadering poog die terapeut om deur herinterpretasie en herstrukturering van die mans se verhale verandering te fasiliteer sodat hulle weer sin en betekenis in hul lewens kan vind. Deur die vertel van hulle narratiewe word ' $n$ bydrae tot die konstruering van ' $\mathrm{n}$ diverse verhaal deur die gespreksgenote gelewer. Die terapeut werk nie met mense nie, maar saam met mense. Uit hulle gesprekke kan afgelei word dat terapie vir die mans van waarde was.

Kobus: 'Ons gesprekke het gehelp dat ek weer perspektief in die lewe gekry het.'

Bernard: 'Dit is die eerste keer dat ek my hart kon uitpraat en dat iemand die rouproses aan my verduidelik het. Ek het gevoel asof ek myself verloor het.'

Louwtjie: 'Ek voel verlig. Daar is iemand wat verstaan. Dit is sommer asof my lewe weer betekenis gekry het.'

Pastoraal terapeutiese betrokkenheid behels hulp van een gelowige aan ander in nood om nuwe betekenis aan hulle lewens te gee. Die terapeut fasiliteer die vertel van die storie, respekteer die mans en aanvaar dat die potensiaal tot heelwording in hulleself geleë is. Dit beteken om met die mans se diskoerse in gesprek te gaan in die lig van God se storie en behels die herstrukturering van die mans se begrip van hoop en vertroosting. God se storie kan help om die verlede sowel as die toekomsstorie só te herformuleer dat dit nuwe sin aan die hede gee. Hoewel dit nie moontlik is om aan die ervaring van eensaamheid te ontkom nie, kan dit verlig en minder pynlik gemaak word.

In gevalle waar daar nie vir die betrokke mans 'n moontlikheid van 'n verbintenisfiguur is nie, kan deur terapeutiese ondersteuning gepoog word om eensaamheid in hulle bepaalde opset te hanteer. Dit word nie direktief gedoen nie aangesien die narratiewe benadering slegs ruimte laat dat medenavorsers bemagtig word om dit te hanteer. Deur moontlike alternatiewe vir die hantering in hulle midde te laat, kan hantering daarvan moontlik gefasiliteer word. Voorstelle gegrond op vorige navorsing van De Beer en Van den Berg (2012:114) met betrekking tot eensaamheid by vroue na verlies van 'n lewensmaat. Dit is die gespreksgenote se besluite en keuses of hulle daaruit ' $n$ moontlike plan wil saamstel om hulle eensaamheid te kan hanteer. Voorbeelde daarvan is die volgende:

- Reik uit na mense. Bly betrokke by aktiwiteite in die gemeenskap. Verbreed jou horisonne.

- Bou goeie verhoudings deur ' $\mathrm{n}$ vriend te wees vir iemand anders.

- Hou op om passief te wees en raak aktief.

- $\quad$ Skakel in by nuwe situasies.

- Reis indien dit binne jou vermoë is.

- Kry 'n nuwe interessante stokperdjie. Bly intellektueel aktief.

- Sluit aan by 'n klub of doen vrywillige werk vir 'n organisasie. Wanneer daar niemand is wat saam met jou kan of wil gaan nie, gaan dan alleen.

- Luister aandagtig na wat iemand sê, vergeet van jouself en toon opregte belangstelling en empatie. 
- Moenie skaam of bang wees om aan te klop vir hulp nie. Wanneer jy depressief en eensaam voel, moet jy met iemand praat wat sal luister.

- Moenie emosionele seerkry of traumatiese gebeure van jou kinderjare of verlede onderdruk nie. Hanteer dit sinvol en bemoedig ander in dieselfde situasie.

Indien gespreksgenote ontvanklik is vir nuwe keuses, besluite, verhoudings en situasies, kan eensaamheid oorkom word en nuwe moontlikhede en potensiaal ontstluit. Dit blyk uit die volgende fragmente van hulle gesprekke.

Kobus: 'Ek is meer gemoedelik, het by kerklike aktiwiteite ingeskakel en kuier nou weer by my bure. Beplan om saam met hulle met vakansie te gaan.'

Bernard: 'Ek ry saam met my kinders rond en het al 'n hele paar interessante mense ontmoet. Besef nou dat ek ook moet uitreik na ander.'

Louwtjie: 'Het 'n goeie vriendin ontmoet wat vir my baie beteken. Sy luister na my wanneer ek wil praat. Hierdie verhouding hou nogal vir my toekomstige moontlikhede in.'

Die strewe is om die mans hoop en vertroosting te bied deur insig, groei en herstel te fasiliteer. Die navorser en medenavorser rekonstrueer die lewensverhaal op soek na sin en betekenis. In die pastorale gesprek is gepoog om nuwe insig in hulle wêreld te fasiliteer.

\section{NAVORSINGSBEPERKINGS}

Daar is in hierdie studie gefokus op die individuele en persoonlike belewenis van eensaamheid en is nie gegrond op algemene afleidings nie. Beperkings in hierdie navorsing is die keuse van slegs drie medenavorsers binne een bepaalde dorp, wat vanuit dieselfde kultuurkonteks, ras en christelike oriëntasie funksioneer.

\section{SLOT}

Die navorser het deurgaans gepoog om die mans se verhale te verstaan en te interpreteer met God se verhaal in gedagte. Daar is 'n pastoraal-teologiese klem aan die aard, karakter, inhoud en uitkomste van hierdie navorsing soos in die fragmente van medenavorsers se gesprekke en literatuurstudie aangedui is.

Na aanleiding van die mans se verhale is dit duidelik dat hulle intense eensaamheid ervaar het na dieverliesvan'nlewensmaat. Hulle verhale moet gesien word teen die agtergrond van die Christelike geloofsgemeenskap. As christene het die mans se geloof ' $n$ belangrike rol gespeel in hulle hantering van eensaamheid. Hulle soeke na kennis en ondersteuning het 'n pastorale inslag. Dit blyk dat hulle belewenis van eensaamheid 'n uitwerking op hulle daaglikse funksionering gehad het. Hulle het 'n leemte ondervind ten opsigte van 'n verbintenisfiguur en het behoefte gehad aan iemand wat hulle kan ondersteun wanneer hulle eensaam is. Die aanname is dat hierdie persoon moontlik terapeutiese riglyne vir hoop en vervulling in hul daaglikse bestaan kan bied.

\section{ERKENNING}

Die outeur verklaar dat sy geen finansiële of persoonlike verbintenis het met enige party wat hulle nadelig of voordelig kon beïnvloed in die skryf van hierdie artikel nie.

\section{LITERATUURVERWYSINGS}

Blackwell, M.S. 2010. Moenie bang wees vir eensaamheid nie, besigtig op 19 Desember 2010, by http://www.mrf.za.net/modules/ftpdocs/users/

Botha, P. 2001. Die kwalitatiewe onderhoud as data-insamelingstegniek: Sterk en swak punte. Journal of Family Ecology and Consumer Sciences, 29, 13-19.

Browning, D.S. 1991. A fundamental practical theology: Descriptive and strategic proposals. Minneapolis: Fortress.

De Beer, A. 2007. Afsluiting na die verlies van 'n kind - 'n Narratiewe pastorale studie van 'n moeder(s) se belewenis, Magister-skripsie, Universiteit van die Vrystaat, Bloemfontein.

De Beer, A. \& Van den Berg, J-A. 2008. "Afsluiting” na die verlies van 'n kind: 'n Narratiewe pastorale studie van 'n moeder(s) se belewenis(se). Praktiese Teologie in Suid-Afrika 23(2), 44-61.

De Beer, A. \& Van den Berg, J.A. 2011. 'n Diskoers oor eskatologie en promissioterapie by vroue na die verlies van 'n eggenoot. In die Skriflig, 45(1), 141-159.

De Beer, A. \& Van den Berg, J.A. 2012. Vroue se belewenis van eensaamheid na die verlies van 'n lewensmaat: 'n Beskrywing van narratiewe pastorale betrokkenheid. Koers, 77(2), 108-116.

Denzin, N.K. \& Lincoln, Y.S. 1994. Introduction: Entering the field of qualitative research, in N.K. Denzin \& Y.S. Lincoln (eds.), 2000, Handbook of qualitative research, 2de uitgawe, pp. 1-17, New York: Sage.

Doman, L.C.H. 2007. 'Die verband tussen eensaamheid en psigologiese welstand by derdejaarstudente: 'n Kruiskulturele ondersoek', MSocSc-skripsie, Departement Sielkunde, Fakulteit Geesteswetenskappe, Universiteit van die Vrystaat, Bloemfontein.

Endres, A. 2009. Getraumatiseerde adolessente se soeke na hoop: 'n Pastorale model. PhD-proefskrif, Universiteit van Pretoria, Pretoria.

Fourie, M.C.F. 2010. 'Middelloopbaan-ontwikkeling deur spirituele lewenstylafrigting', PhD-proefskrif, Departement Praktiese Teologie, Fakulteit Teologie, Universiteit van die Vrystaat, Bloemfontein.

Freedman, J. \& Combs, G. 1996, Narrative therapy: The social construction of preferred realities. New York: Norton.

Ganzevoort, R.R. \& Visser, J. 2007. Zorg voor het verhaal. Achtergrond, methode en inhoud van pastorale begeleiding. Zoetermeer: Meinema.

Heitink, G. 1979. Pastoraat als hulpverlening: Inleiding in de pastorale theologie en psychologie. Kampen: Kok.

Josselson, R. 1999. 'Introduction', in R. Josselson \& A. Lieblich (eds.), Making meaning of narratives: The narrative study of lives. Volume 6, pp. ix-xiii, London: Sage.

Kotzé, D. 2002. 'Doing participatory ethics', in D. Kotzé, J. Myburgh, J. Roux et al. (reds.), Ethical ways of being, pp. 1-34, Ethics Alive, Pretoria.

Kruger, S.F. 2000. Menslike persoonlikheid en toerustende herderlike bediening: Aspekte van 'n metateorie, basisteorie en praktykteorie. PhD-proefskrif, Potchefstroomse Universiteit vir Christelike Hoër Onderwys, Potchefstroom. 
Kübler-Ross, E. \& Kessler, D. 2005. On grief and grieving: Finding the meaning of grief through the five stages of loss. London: Simon \& Schuster.

Lauder, W., Sharkey, S. \& Mummery, K. 2004. Nursing and health care management and policy: A community survey of loneliness. Journal of Advanced Nursing 46(1), 88-94.

Leaf, C. 2011. Wie het jou brein afgeskakel? Verstaan die verskillende maniere waarop mans en vroue kommunikeer. Kaapstad: Struik Christelike Boeke.

Louw, D.J. 1997. Hoe teologies is die praktiese teologie en hoe prakties is die teologie? Ontwerp vir 'n prakties-teologiese hermeneutiek. Praktiese Teologie in Suid-Afrika, 12(2), 43-63.

Louw, D.J. 1999. Pastoraat as vertolking en ontmoeting: 'n Teologiese ontwerp vir ' $n$ basisteorie, antropologie, metode en terapie, hersiene uitgawe, Kaapstad: Lux Verbi.

Louw, D. 2008. Cura Vitae. Illness and the healing of life. Wellington: Lux Verbi BM.

McClure, B. 2012. 'Pastoral Care', in B.J. Miller-McLemore (ed.), The Wiley-Blackwell Companion to Practical Theology, pp. 269-278, Oxford: Wiley-Blackwell.

Morgan, A. 2000. What is narrative therapy? An easy-to-read introduction. Adelaide Dulwich Centre Publications.

Müller, J. 1996. Om tot verhaal te kom. Pretoria: RGN.

Müller, J., Van Deventer, W. \& Human, L. 2001. Fiction writing as metaphor for research: A narrative approach. Practical Theology in South Africa 16(2), 76-96.

Müller, J. 2009. Transversal rationality as a practical way of doing interdisciplinary work, with HIV and Aids as a case study. Practical Theology in South Africa 24(2), 199-228.

Osmer, R.R. 2008. Practical theology: An introduction. Wm B Eerdmans, Michigan.

Paul C, Ayis S \& Ebrahim, S. 2006. Psychological distress, loneliness and disability in old age. Psychology, Health and Medicine 11(2):221-232.

Peplau, L.A. \& Perlman, D. 1982. Loneliness: A sourcebook of current theory, research and therapy. New York: Wiley-Interscience Publication.

Perlman, D. 1989. Further Reflections on the present state of loneliness research, in M. Hojat \& R. Crandall (eds.), Loneliness: Theory, research and applications, London: Sage.

Perlman, D. \& Joshi, P. 1989. The relationship of interpersonal competence and skills to reported loneliness across time, in M. Hojat \& R. Crandall (eds.), Loneliness: Theory, research and applications. London: Sage.

Pike, J.A. 1953. Beyond Anxiety. The Christian answer to fear, frustration, guilt, indecision, inhibition, loneliness, despair. New York: Charles Scribner's Sons.

Potgieter, S.T. 2010. Eensaamheid, besigtig op 19 Desember 2010, by http://centralsa. womf.com/blog.php?id=108631

Schurink, E.M. 1998. Deciding to use a qualitative research approach. In Research at grass roots. A primer for the caring professions. A.S. De Vos. Academic, JL. van Schaik: Pretoria.

Shaver, P. \& Hazan, C. 1989. The relationship of interpersonal competence and skills to reported loneliness across time, in M. Hojat \& R. Crandall (eds.), Loneliness: Theory, research, and applications. London: Sage.

Spitzberg, B.H. \& Hurt, H.T. 1989. The relationship of interpersonal competence and skills to reported loneliness across time, in M. Hojat \& R. Crandall (eds.), Loneliness: Theory, research, and applications London: Sage.

Stokes, J.P. 1989. The relationship of interpersonal competence and skills to reported loneliness across time, in M. Hojat \& R. Crandall (eds.), Loneliness: Theory, research, and applications. London: Sage.
Taylor, S.E., Peplau, L.A. \& Sears, D.O. 2003. Social Psychology (11 $1^{\text {th }}$ Edition). New Jersey: Prentice Hall.

Weiss, R.S. 1989. Reflections on the present state of loneliness research, in M. Hojat \& R. Crandall (eds.), Loneliness: Theory, research, and applications London: Sage.

Wintrob, H.L. 1989. Self disclosure as a marketable commodity, in M. Hojat \& R. Crandall (eds.). Loneliness: Theory, research, and applications. London: Sage.

Wood, L.A. 1989. Loneliness: Physiological or linguistic analysis?, in M. Hojat \& R. Crandall (eds.). Loneliness: Theory, research, and applications. London: Sage. 